\title{
Application of plant-based natural additives to improve the bioactive properties of organic artisanal cheeses
}

\author{
Waldemar Gustaw, Katarzyna Skrzypczak, Ewa Jabłońska-Ryś, \\ Aneta Sławińska, Wojciech Radzki, Bartosz Sołowiej
}

University of Life Sciences in Lublin, Lublin

Keywords:

Cheese

Organic

Lactic acid

Antioxidant

Bioactive

Article history:

Received

23.06.2019

Received in revised

form 02.12.2019

Accepted

30.03.2020

Corresponding

author:

Katarzyna

Skrzypczak

E-mail:

katarzyna.

skrzypczak@

up.lublin.pl

DOI:

10.24263/2304-

974X-2020-9-1-6

\section{Abstract}

Introduction. The aim of research was to increase the content of bioactive substances and improving antioxidative properties of organic artisanal cheeses by application the selected organic vegetable additives into manufacture of cheeses.

Materials and methods. In the produced organic cheeses containing selected organic vegetable additives the antioxidant propertied were determined by analyzing the ferric reducing antioxidant power. Series of spectrophotometric measurement were performed to determine the content of polyphenolic substances and other selected bioactive components including: carotenoids, lycopene, chlorophyll, anthocyanins, flavonoids and betalains.

Results and discussion. The findings revealed that the antioxidant activity of the tested products ranged from $1.48 \pm 0.11 \mu \mathrm{mol}$ of Trolox $/ \mathrm{g}$ (variant of control cheese after ripening) to $4.1 \pm 0.3 \mu \mathrm{mol}$ of Trolox $/ \mathrm{g}$ (cheese containing tomatoes tested after ripening). In turn, the content of total phenolic compounds in cheeses immediately after ripening ranged from $141.51 \pm 2.38 \mathrm{mg} \mathrm{GAE} / 100 \mathrm{~g}$ (in the control variant) to $289.9 \pm 9.9 \mathrm{mg} \mathrm{GAE} / 100 \mathrm{~g}$ (in cheese with addition of dried tomatoes). The final products with the addition of broccoli and tomato after refrigerated storage exhibited the highest antioxidant properties in comparison to other tested products. Furthermore, after the maturation process total carotenoids content in the organic cheeses produced with organic carrot and tomato additives correspond to the results of the antioxidant activity assay. Moreover, cheeses containing the dried tomato additives were characterized by the highest acidity associated with the content of lactic acid after ripening $(2.33 \pm 0.02 \mathrm{~g} / 100 \mathrm{~g}$ of cheese) and after refrigerated storage $(2.51 \pm 0.03 \mathrm{~g} / 100 \mathrm{~g}$ of cheese); simultaneously, these products exhibited the highest values of total phenolic contents. The refrigerated storage of cheeses reduced the hardness and adhesion values only in the case of cheeses produced with the addition of onions, while the other variants showed an increase in this parameter after the end of the refrigerated storage. All vegetable additives contributed to an increase in the red color in the cheeses.

Conclusions. The tested additives increased the level of bioactive components and antioxidant properties of cheeses after ripening and also positively influenced on their color. 


\section{Introduction}

Due to the fact that transparent packaging is very often used for packaging dairy products, the photo-oxidation reactions of cheeses have become a problem [1]. This issue concerns in particular artisanal organic cheeses, where the manufactured products most often remain unpackaged. An excessive oxidation induces undesirable changes in properties of cheeses including aroma, taste and alterations in external appearance. Moreover, oxidation of proteins and amino acids affects the formation of undesired off-flavour constituents [1]. However, some of the organic products possessing natural antioxidants that might protect from intensive oxidation processes (that are additionally strengthened by photo-oxidation) [2-5]. Also, there is currently a growing interest and demand for healthy cheeses [5-7], nonetheless a limited research is still available on the use of organic fruit and vegetable additives to fortify cheese products. Therefore, the objective of the investigation was to develop a natural method increasing content of bioactive substances and improving antioxidative properties of organic artisanal cheeses. The aim of research is also to evaluate the influence of application the selected, organic vegetables-derived additives on the changes of antioxidant activities and other physicochemical parameters of ripening cheeses. The investigation analyzed also the possibility of using the tested additives as a natural alternative to conventional cheese dyes and also functional components that might improve the health promoting characteristics of organic cheeses.

\section{Materials and methods}

\section{Materials}

Cow's milk purchased from a certified organic farm (No. PL-EKO-07-04210) from Lublin Province (Krupe, Poland) was used for production of ripened cheeses. The chemical composition of raw milk $(\mathrm{g} / 100 \mathrm{~g})$ was as follows: lactose 4.48 , fat 3.45 , protein 3.14 (before production, samples of milk were analyzed by infrared spectrophotometry using the MilkoScan 4000 apparatus according to Michaelsen et al. [6]. The average total number of microorganisms in the raw material samples estimated with the Fossomatic 5000 apparatus was below $100,000 / \mathrm{ml}$, while the number of somatic cells was on average $282,000 / \mathrm{ml}$. The hygienic quality of milk obtained from the organic farm and its technological suitability met the requirements for raw materials intended for the production of ripening cheeses.

Organic vegetables (with certificates confirming compliance with the requirements for organic raw material) purchased in organic food stores were used as additives in the production of cheeses (Table 1).

Table 1

List of plant raw materials

\begin{tabular}{|c|c|c|}
\hline Raw plant material & Variety & $\begin{array}{l}\text { Name of distribution } \\
\text { company }\end{array}$ \\
\hline Onion (Allium cepa L.) & Red Baron & \multirow{4}{*}{$\begin{array}{c}\text { Farma Świętokrzyska Sp. z } \\
\text { o.o., Warsaw, Poland }\end{array}$} \\
\hline Beetroot (Beta vulgaris $\mathrm{L})$ & Wodan & \\
\hline Carrot (Daucus carota L.) & Nerac & \\
\hline Tomato (Lycopersicon esculentum Mill.) & Jack & \\
\hline Broccoli (Brassica oleracea L.) & Kronos & $\begin{array}{l}\text { Przedsiębiorstwo Handlowo - } \\
\text { Usługowe, Cedzyna, Poland }\end{array}$ \\
\hline
\end{tabular}


Fresh vegetables were individually pre-treated by washing, removing unnecessary parts, shredding (roots of carrots and beet - chips with a thickness of $2 \mathrm{~mm}$, onions and fruits of tomatoes - cubes with sides of 5-7 mm, broccoli - florets not exceeding $15 \mathrm{~mm}$ ), and blanching (except for tomato) at $95{ }^{\circ} \mathrm{C} / 60 \mathrm{~s}$. Afterwards, shredded plant material was subjected to convection drying (separately each type of vegetable) in a food dehydrator SFD $1205 \mathrm{WH}$ (Sencor, Poland) at $50{ }^{\circ} \mathrm{C}$ for $36 \mathrm{~h}$.

The content of water (moisture) in all dried vegetables was determined in accordance with the method described by Lucera et al. [7].

\section{Cheese manufacture}

Freeze-dried heterofermentative culture Alpha 10 DL 3,5 (Ets A. COQUARD, Villefranche sur Saone, France) containing Lactococcus lactis subsp. lactis, Lactococcus lactis subsp. cremoris, Lactococcus lactis subsp. lactis biovar diacetylactis, Leuconostoc cremoris, and Leuconostoc mesenteroides was used for production of six variants of cheeses.

Each cheese variant was made with $10 \mathrm{~L}$ of pasteurized $\left(74{ }^{\circ} \mathrm{C}, 5 \mathrm{~min}\right)$ milk supplemented with $2 \mathrm{ml}$ of an aqueous $\mathrm{CaCl}_{2}$ solution $(40 \%)$ after cooling $\left(33{ }^{\circ} \mathrm{C}\right)$. Afterwards, the starter culture was added to the milk according to the manufacturer's recommendation and incubated for $45 \mathrm{~min}$. Subsequently, rennet (CHYMOGEN Premium Plus ${ }^{\circledR}$, Chr. Hansen, Denmark) was added into the milk in a cheese vat (according to the manufacturer's instructions). After the coagulation process $\left(33^{\circ} \mathrm{C} / 35 \mathrm{~min}\right)$, when the proper consistency of the curd was obtained, the coagulum was cut into cubes $(3-5 \mathrm{~mm})$, left for 5 min at $33^{\circ} \mathrm{C}$, and gently stirred for $15 \mathrm{~min}$ raising the temperature gradually $\left(1^{\circ} \mathrm{C} / 2 \mathrm{~min}\right)$ up to $37{ }^{\circ} \mathrm{C}$. Then, $40 \%$ of whey was removed and replaced with the same amount of water at the temperature of $35^{\circ} \mathrm{C}$. The cooking process (with constant stirring of cheese grains) was carried out until the acidity of the curd was pH 6.4-6.5. Then, the whey was drained off and a previously prepared portion of dried organic vegetables (onion, beetroot, broccoli, carrot, or tomato) was added to the cheese mass at a level of $5 \%$ (per $1 \mathrm{~kg}$ of cheese curd) and thoroughly mixed. Cheeses without any vegetable addition were the control variant. The cheese mass was divided into three equal portions $(300 \mathrm{~g})$, transferred into microperforated plastic (round) molds, and rotated every $45 \mathrm{~min}$ to drain off the whey effectively.

After molding, the cheeses were pressed at $18^{\circ} \mathrm{C}$ for $4.5 \mathrm{~h}$ by applying $2 \mathrm{~kg} / \mathrm{h}$ pressure on the top of the round molds $(13 \times 7 \mathrm{~cm})$ to the final load of $6 \mathrm{~kg}$. Fresh cheeses were salted by immersion in saturated brine $\left(18 \% \mathrm{NaCl}, \mathrm{pH}=4.8\right.$; temp $\left.13^{\circ} \mathrm{C} / 6 \mathrm{~h}\right)$ and turned over every $45 \mathrm{~min}$. Then, the cheeses were thoroughly dried $\left(13^{\circ} \mathrm{C} / 24 \mathrm{~h}\right)$, covered with a polyacetate coating, and transferred to the ripening room for 21 days $\left(13^{\circ} \mathrm{C} / 85 \%\right.$ relative humidity $)$. After this time, they were placed in a cold chamber $\left(5^{\circ} \mathrm{C}\right)$ for six-week storage.

\section{Determination content of selected bioactive components}

The contents of selected biologically active substances (characteristic for each type of plant material) in the variants of cheeses containing one type of the tested vegetable additive were determined using the below-mentioned methods.

The lycopene content in cheeses $(\mathrm{mg} / 100 \mathrm{~g}$ of product) that contained tomato supplementation was determined with the method described by Fish et al. [8].

The content of chlorophyll ( $\mathrm{a}$ and $\mathrm{b}$ ) in cheeses $(\mathrm{mg} / 100 \mathrm{~g}$ of product) containing broccoli additive was analyzed according to protocol developed by Lichtenthaler and Buschmann [9]. In turn, the content of betalains in cheeses containing beetroot supplement was analyzed by using the method described by Gościnna et al. [10] involving the simultaneous determination of purple betacyanins and yellow betaxanthins. 
The concentration of anthocyanins in variants of cheeses (mg/100 $\mathrm{g}$ of product) containing dried onion was determined using the protocol of quantitative methods for anthocyanins developed by Fuleki and Francis [11]. While, the content of flavonoids was analyzed according to Jia et al. [12]. The absorbance was determined (against blank) at 510 nm using Helios Gamma apparatus (Thermo Fisher Scientific, Waltham, MA, USA). The flavonoid content was calculated using the standard calibration curve (prepared with rutin solutions) and expressed in $\mathrm{mg} / 100 \mathrm{~g}$ of the tested product.

Determination of total phenolic contents in all variants of cheeses was performed according to Jabłońska-Ryś et al. [13]. The absorbance was measured by Helios Gamma apparatus (Thermo Fisher Scientific, Waltham, MA, USA) at $\lambda=765 \mathrm{~nm}$. The results were expressed as $\mathrm{mg}$ gallic acid per $100 \mathrm{~g}$ of cheese.

The sum of carotenoids and $\beta$-carotene in all variants of cheeses was determined according to [14].

The titratable acidity was determined according to AOAC (Method 920.124) [15] and expressed as g lactic acid/100 g cheese.

All chemical analyses were performed in triplicate.

\section{Determination antioxidant activities}

The antioxidant activity of all produced variants of cheeses was determined by analyzing the ferric reducing antioxidant power (FRAP) of the tested samples to reduce according to the method described by Radzki et al. [16] with some modifications. In brief, the prepared FRAP reagent contained mixture of $300 \mathrm{mM}$ acetate buffer ( $\mathrm{pH}$ 3.6) with a 2,4,6-tri(2-pyridyl)-1,3,5-triazine (TPTZ) (Sigma-Aldrich) solution (10 mM TPTZ in $40 \mathrm{mM}$ $\mathrm{HCl}$ ), and a $20 \mathrm{mM} \mathrm{FeCl} 3 \cdot 6 \mathrm{H}_{2} \mathrm{O}$ solution (at 10:1:1 ratio). The tested material was subjected to extraction by adding $30 \mathrm{~mL}$ of water (distillated, sterile) in to $1 \mathrm{~g}$ samples (and mixing in a shaker (Elpan 357; Elpan, Lubawa, Poland) at $50{ }^{\circ} \mathrm{C}$ and 5.000xg for $1 \mathrm{~h}$. After centrifugation at $4,800 \times \mathrm{g}$ for $15 \mathrm{~min}$ (MPW350-R; MPW) $100 \mu \mathrm{L}$ of obtained clear supernatants were thoroughly mixed with $1.9 \mathrm{~mL}$ of FRAP reagent and incubated for at 37 ${ }^{\circ} \mathrm{C} 90 \mathrm{~min}$ in darkness. Then, the absorbance was measured at $593 \mathrm{~nm}$ applying the Helios Gamma apparatus (Thermo Fisher Scientific, Waltham, MA, USA). Ferric reducing antioxidant power was calculated using the calibration curve prepared with Trolox aqueous solutions. The results were expressed in Trolox $\mu \mathrm{M}$ or per $1 \mathrm{~g}$ of cheese ( $\mu \mathrm{M}$ Trolox $/ \mathrm{g}$ ).

\section{Texture profile analysis (TPA)}

Measurements were performed with a TA-XT2i Texture Analyser (Stable Micro Systems, Godalming, UK) according to Sołowiej [17]. All analyzed cheese samples had the same size and shape (rolls $1.5 \mathrm{~cm}$ high and $1.5 \mathrm{~cm}$ wide) and were double compressed to $50 \%$ of deformation by a testing set ( $15 \mathrm{~mm}$ diameter). The compression rate was equal to $1 \mathrm{~mm} / \mathrm{s}$. The following texture parameters: hardness, adhesiveness, fracturability, cohesiveness, gumminess, and chewiness were evaluated.

\section{Determination salt and fat contents}

The salt concentration in the cheeses was determined with the Mohr method according to [18] and expressed as a percentage (\%) of sodium chloride.

Determination of the total fat content was performed in accordance with ISO 1735:2004 [19] using a Soxtec Avanti 2055 device (Foss Tecator, Höganäs, Sweden). 


\section{Analysis of color parameters}

Measurement of color parameters of the cheeses in the CIE $\mathrm{L}^{*} \mathrm{a}{ }^{*} \mathrm{~b}^{*}$ system was performed according to Carini et al. [20] using an X-RiteColor 8200 colorimeter (X-Rite Inc.) and X-Rite Color Master software. For each variant of the product, the measurement was made over the entire surface of horizontally cut rings $(\varnothing 12 \mathrm{~cm}, 5 \mathrm{~cm}$ thick) of cheese mass. Every sample was analyzed over the entire surface (evenly) in a ten-fold repetition (the measurements were collected from the surface of the cheese matrix). The $\mathrm{L}^{*}, \mathrm{a}^{*}$, and $\mathrm{b}^{*}$ values ( $\mathrm{L}^{*}$ : brightness, $\mathrm{a}^{*}$ : redness-greenness, $\mathrm{b}^{*}$ : yellowness-blueness) were measured between 390 and $700 \mathrm{~nm}$ (D65 illuminant, 10 ${ }^{\circ}$ standard observer, $\varnothing 13 \mathrm{~mm}$ port size) using a white standard with the following parameters: $L^{*}=-95.87, a^{*}=-0.49$, and $b^{*}=2.39$.

\section{Statistical analysis}

Statistical analysis was performed with the STATISTICA 13.1 program (StatSoft, Inc., USA). The results were presented as mean values with their standard deviations (mean $\pm \mathrm{SD}$ ). The analysis of variance (ANOVA) was applied using Tukey's HSD test in order to estimate the significance of the differences between the mean values. The results were discussed based on a significance level set at $\mathrm{P}<0.05$.

\section{Results and discussion}

\section{Content of selected bioactive components and determination of antioxidant activities}

The content of selected biologically active compounds was determined in organic cheeses containing addition of dried vegetables (Table 2 ). The analyses were performed after ripening and after refrigerated storage (Table 3 ).

Moisure level of the dried vegetables used in cheese production

Table 2

\begin{tabular}{|c|c|c|c|c|c|}
\cline { 2 - 6 } \multicolumn{1}{c|}{} & \multicolumn{5}{c|}{ Type of dried vegetable } \\
\cline { 2 - 6 } \multicolumn{1}{c|}{ Onion } & Broccoli & Beetroot & Carrot & Tomato \\
\hline Moisure [\%] & $6.0 \pm 0.01^{\mathrm{a}}$ & $7.6 \pm 0.02^{\mathrm{b}}$ & $7.8 \pm 0.03^{\mathrm{b}}$ & $8.1 \pm 0.01^{\mathrm{c}}$ & $9.1 \pm 0.03^{\mathrm{d}}$ \\
\hline
\end{tabular}

Explanation notes: The results are given as mean values \pm standard deviation $(\overline{\mathrm{x}} \pm \mathrm{s} / \mathrm{SD} ; \mathrm{n}=3)$.

The lowercase letters $(\mathrm{a}-\mathrm{d})$ express significant differences $(\mathrm{P}<0.05)$ between values.

Carotenoids are biologically active substances with a high potential of positive effects on the human body. These compounds demonstrate a wide spectrum of health-promoting properties, especially in the prevention and alleviation of cardiovascular disease [21]. Therefore, the selected plant-based raw materials were applied in the production of organic cheeses as a source of the above-mentioned functional substances.

Lycopene is considered as an important component in prevention some cardiovascular diseases and formation of tumors and is estimated that in ripe tomatoes fruits accounts to 80$90 \%$ of the total pigment contents [22]. Therefore, high expectations are associated with the possibility of application this bioactive component in the prevention and therapy of prostate cancer [23]. 
Table 3

Comparison of antioxidant activities and the content of bioactive substances and other components in the variants of organic cheeses

\begin{tabular}{|c|c|c|c|}
\hline \multirow{2}{*}{$\begin{array}{c}\text { Analyzed } \\
\text { parameter/content } \\
\text { of substances }\end{array}$} & \multirow[b]{2}{*}{ Cheese variant } & \multicolumn{2}{|c|}{ Stage of cheese production } \\
\hline & & After ripening & After refrigerated storage \\
\hline $\begin{array}{c}\text { Carotenoids } \\
{[\mathrm{mg} / \mathbf{1 0 0 g}]}\end{array}$ & $\begin{array}{l}\text { Control } \\
\text { With onion } \\
\text { With tomato } \\
\text { With carrot } \\
\text { With broccoli } \\
\text { With beetroot }\end{array}$ & $\begin{array}{c}0.43 \pm 0.02^{\mathrm{g}} \\
0.42 \pm 0.03^{\text {cd }} \\
6.37 \pm 0.20^{\mathrm{j}} \\
5.82 \pm 0.20^{\mathrm{i}} \\
0.94 \pm 0.05^{\text {ef }} \\
0.42 \pm 0.02^{\mathrm{fg}}\end{array}$ & $\begin{array}{c}0.38 \pm 0.02^{\mathrm{c}} \\
0.46 \pm 0.04^{\mathrm{b}} \\
6.22 \pm 0.10^{\mathrm{k}} \\
5.57 \pm 0.03^{\mathrm{h}} \\
0.94 \pm 0.04^{\mathrm{de}} \\
0.26 \pm 0.01^{\mathrm{a}}\end{array}$ \\
\hline Lycopene [mg/100g] & With tomato & $6.01 \pm 0.23^{\mathrm{b}}$ & $5.56 \pm 0.18^{\mathrm{a}}$ \\
\hline Chlorophyll A [mg/100g ] & With broccoli & $0.86 \pm 0.05^{\mathrm{b}}$ & $0.52 \pm 0.01^{\mathrm{a}}$ \\
\hline Chlorophyll B [mg/100g ] & With broccoli & n.d. & n.d. \\
\hline Anthocyanins [mg/100g] & With onion & $7.71 \pm 0.44^{\mathrm{b}}$ & $6.61 \pm 0.16^{\mathrm{a}}$ \\
\hline Flavonoids [mg/100g ] & With onion & $12.84 \pm 0.22^{\mathrm{b}}$ & $9.77 \pm 0.80^{\mathrm{a}}$ \\
\hline Betalains [mg/100g ] & With beetroot & $0.25 \pm 0.03^{\mathrm{a}}$ & $0.22 \pm 0.02^{\mathrm{a}}$ \\
\hline $\begin{array}{c}\text { Lactic acid } \\
\text { [g/100 g cheese] }\end{array}$ & $\begin{array}{l}\text { Control } \\
\text { With onion } \\
\text { With tomato } \\
\text { With carrot } \\
\text { With broccoli } \\
\text { With beetroot }\end{array}$ & $\begin{array}{c}1.37 \pm 0.03^{\mathrm{a}} \\
1.92 \pm 0.00^{\mathrm{f}} \\
2.33 \pm 0.02^{\mathrm{i}} \\
1.85 \pm 0.00^{\mathrm{de}} \\
1.5 \pm 0.03^{\mathrm{b}} \\
1.67 \pm 0.00^{\mathrm{c}}\end{array}$ & $\begin{array}{c}1.91 \pm 0.03^{\text {ef }} \\
2.07 \pm 0.00^{\mathrm{gh}} \\
2.51 \pm 0.03^{\mathrm{j}} \\
1.83 \pm 0.03^{\mathrm{d}} \\
2.00 \pm 0.03^{\mathrm{fg}} \\
2.07 \pm 0.00^{\mathrm{h}}\end{array}$ \\
\hline $\begin{array}{c}\mathrm{NaCl} \\
{[\%]}\end{array}$ & $\begin{array}{l}\text { Control } \\
\text { With onion } \\
\text { With tomato } \\
\text { With carrot } \\
\text { With broccoli } \\
\text { With beetroot }\end{array}$ & $\begin{array}{c}0.73 \pm 0.02^{\mathrm{a}} \\
0.82 \pm 0.02^{\mathrm{ab}} \\
0.84 \pm 0.02^{\mathrm{bc}} \\
0.92 \pm 0.00^{\text {cde }} \\
0.86 \pm 0.02^{\text {bcd }} \\
0.95 \pm 0.02^{\text {def }}\end{array}$ & $\begin{array}{c}0.74 \pm 0.00^{\mathrm{a}} \\
0.82 \pm 0.02^{\mathrm{ab}} \\
0.91 \pm 0.02^{\mathrm{bcde}} \\
0.99 \pm 0.00^{\mathrm{ef}} \\
0.96 \pm 0.02^{\text {def }} \\
1.03 \pm 0.02^{\mathrm{f}} \\
\end{array}$ \\
\hline $\begin{array}{c}\text { Total fat } \\
{[\%]}\end{array}$ & $\begin{array}{l}\text { Control } \\
\text { With onion } \\
\text { With beetroot } \\
\text { With carrot } \\
\text { With broccoli } \\
\text { With tomato }\end{array}$ & $\begin{array}{l}26.5 \pm 1.8^{\mathrm{a}} \\
29.7 \pm 2.1^{\mathrm{a}} \\
29.2 \pm 2.0^{\mathrm{a}} \\
25.5 \pm 1.8^{\mathrm{a}} \\
26.8 \pm 1.9^{\mathrm{a}} \\
28.7 \pm 2.0^{\mathrm{a}}\end{array}$ & $\begin{array}{l}26.9 \pm 1.9^{\mathrm{a}} \\
30.2 \pm 2.1^{\mathrm{a}} \\
29.9 \pm 2.1^{\mathrm{a}} \\
25.9 \pm 1.8^{\mathrm{a}} \\
28.1 \pm 2.0^{\mathrm{a}} \\
29.8 \pm 2.1^{\mathrm{a}}\end{array}$ \\
\hline $\begin{array}{c}\text { TPC } \\
\text { [mg GAE /100g of } \\
\text { cheese] }\end{array}$ & $\begin{array}{l}\text { Control } \\
\text { With onion } \\
\text { With tomato } \\
\text { With carrot } \\
\text { With broccoli } \\
\text { With beetroot }\end{array}$ & $\begin{array}{c}142 \pm 2.00^{\mathrm{a}} \\
185 \pm 3.00^{\text {cde }} \\
290 \pm 10.00^{\mathrm{f}} \\
166 \pm 7.00^{\text {abc }} \\
170 \pm 7.00^{\text {bcd }} \\
187 \pm 6.00^{\text {cde }}\end{array}$ & $\begin{array}{c}163 \pm 4.00^{\mathrm{abc}} \\
157 \pm 9.00^{\mathrm{ab}} \\
294 \pm 13.00^{\mathrm{f}} \\
173.3 \pm 3.00^{\mathrm{bcd}} \\
200 \pm^{\mathrm{de}} 14.00^{\mathrm{e}} \\
194 \pm 12.00^{\mathrm{de}}\end{array}$ \\
\hline $\begin{array}{c}\text { FRAP } \\
{[\mu \mathrm{mol} \text { Trolox } / \mathrm{g}]}\end{array}$ & $\begin{array}{l}\text { Control } \\
\text { With onion } \\
\text { With tomato } \\
\text { With carrot } \\
\text { With broccoli } \\
\text { With beetroot }\end{array}$ & $\begin{array}{c}1.48 \pm 0.11^{\mathrm{a}} \\
1.98 \pm 0.32^{\mathrm{abc}} \\
4.1 \pm 0.30^{\mathrm{f}} \\
2.50 \pm 0.10^{\mathrm{cd}} \\
2.08 \pm 0.29^{\mathrm{abcd}} \\
2.25 \pm 0.20^{\mathrm{bcd}}\end{array}$ & $\begin{array}{c}1.76 \pm 0.18^{\mathrm{ab}} \\
1.55 \pm 0.22^{\mathrm{a}} \\
2.7 \pm 0.10^{\mathrm{de}} \\
1.80 \pm 0.10^{\mathrm{ab}} \\
3.28 \pm 0.28^{\mathrm{e}} \\
2.03 \pm 0.28^{\mathrm{abcd}}\end{array}$ \\
\hline
\end{tabular}

Explanation notes: The results are given as mean values \pm standard deviation $(\overline{\mathrm{x}} \pm \mathrm{s} / \mathrm{SD} ; \mathrm{n}=3)$. The lowercase letters (a-f) in the same row that presents the analyzed parameter in all the tested cheese variants (after ripening and after refrigerated storage) express significant differences $(\mathrm{P}<0.05)$; n.d.not detected; TPC - Total phenolic contents; FRAP - Ferric reducing antioxidant power. 
The application of vegetable additives such as carrot, tomato and broccoli contributed to enrichment of the organic cheeses with carotenoids (Table 3). After the refrigerated storage the highest content of carotenoids was observed in cheeses containing tomato and carrot additives. Moreover, the lycopene content was analyzed in the cheeses with the addition of tomatoes. The content of this bioactive compound in the cheeses after the ripening process (Table 3) reached the level of $6.01 \mathrm{mg} / 100 \mathrm{~g}$, but after cool-storage this value slightly decreased $(5.56 \mathrm{mg} / 100 \mathrm{~g})$.

It has been reported that milk from pasture feeding may be less vulnerable to light oxidation [24]. Furthermore, some authors have indicated that $\beta$-carotene may be a proper biomarker allowing distinguishing dairy products that derive from milk of animals fed in the pasture system from milk of animals subjected to other feeding conventions [25]. However, it is difficult to establish unequivocally that the antioxidant effect is caused only by $\beta$ carotene, since milk (especially that obtained from the pasture system) contains high levels of other components exhibiting antioxidant properties e.g. lactoferrin, vitamins $\mathrm{C}$ and $\mathrm{E}$ or tocopherols [24].

Carotenoids act as singlet oxygen scavengers exhibiting strong antioxidant properties, and $\beta$-carotene seems to be an important factor in the prevention of photo-oxidation mainly because it absorbs light depending on the concentration [24].

The results of the determination the total carotenoid content in the organic cheeses containing the carrot and tomato additives after the maturation process correspond to the results of the antioxidant activity assay (Table 3 ).

It is worth mentioning that tomato lycopene has been perceived as a natural food colorant that is effective in low concentrations, resistant to heat treatment, and stable at extreme $\mathrm{pH}$ values occurring in various stages of food processing [23]. Cheeses containing the dried tomato additive were characterized by the highest acidity associated with the content of lactic acid $(2.33 \pm 0.02 \mathrm{~g} / 100 \mathrm{~g}$ of cheese after ripening and $2.51 \pm 0.03 \mathrm{~g} / 100 \mathrm{~g}$ of cheese after refrigerated storage); simultaneously, these products exhibited the highest values of total phenolic contents (Table 3).

It is suggested that lycopene extract from tomato can be used as a food/dietary supplement e.g. as an antioxidant in products thus contributing to their specific functional value [23]. This is consistent with the present results indicating that the highest antioxidant activity of all the variants of organic cheeses was exhibited (after the ripening period) by products containing the tomato addition (Table 3). Moreover, the intensive color of dried tomatoes and carrots as well as their taste and smell had a decisive influence on the choice of these dried materials in the production of ripening cheeses.

The content of chlorophyll A in cheese with the addition of broccoli after the maturation period reached $0.86 \mathrm{mg} / 100 \mathrm{~g}$; after the cooling storage period, this value decreased to 0.52 $\mathrm{mg} / 100 \mathrm{~g}$ (Table 3). Interestingly, no chlorophyll B fraction was found in the ripened and cool-stored cheeses (this fraction was found only in dried broccoli), which suggests that the fraction may have been decomposed in the technological process of cheese production.

It has been suggested that the absence of blanching (as it happens with fermentation) as well as the enzymatic activity of lipases, lipoxygenases, and peroxidases contribute to changes in chlorophyll enhancing formation of pheophytins, which results in a decrease in the content of chlorophyll and development of brown color [26]. It corresponds to the present results, which indicate that the technology of organic cheese manufacture used (lactic acid fermentation) changes the chlorophyll content in products supplemented with broccoli. This negative effect may probably have been limited by blanching the raw material before further preparation thereof as a dried additive. 
The content of anthocyanins and flavonoids was analyzed in cheeses with the addition of red onions. The content of anthocyanins in the ripened cheeses slightly decreased after the cooling storage and amounted to $6.61 \mathrm{mg} / 100 \mathrm{~g}$. Similarly, the content of flavonoids decreased in the stored product (Table 3). Also, in cheeses containing dried red beetroot the content of betalain pigments decreased after storage (in comparison to samples of this cheeses variant collected after reining process) however the changes in these values were not statistically significant $(\mathrm{P}>0.05)$.

Obtained results indicate that the process of refrigerated storage contributes to the reduction of the content of some bioactive components used as natural cheese dyes.

It has been suggested the use of phenolic compounds as nutrients to enhance the functional properties of milk as well as various dairy products, including cheeses [27, 28] therefore, the obtained in the investigations results are relevant and have considerable practical application.

The application of the tested vegetable additives in cheese manufacture contributes significantly to an increase in the total phenolic content in ripened cheese (compared to the control cheese variant) (Table 3). A similar effect was described by Lucera et al. [7] who enriched spreadable cheese with flours from by-products derived from red and white grape pomace, broccoli, corn bran, and artichokes. They showed that the additives used influenced increased the content of flavonoids and TPC in the products.

The cheese storage had a varied effect on the content of phenolic compounds (Table 3). In case of the cheeses with broccoli and control products, a slight increase in the content of polyphenolic compounds was noted. In turn, a decrease in the total content of phenolic compounds was observed in the case of cheeses with the addition of onion. Moreover, the results indicate that the addition of vegetables did not result in significant differences in the fat content of the cheese (Table 3). A similar finding was reported in studies in which green tea extract was added to full fat cheese [29]. The addition of the extract significantly improved the antioxidant properties of the products (which is also consistent with the results of the antioxidant assay obtained for the cheeses at the end of the ripening process) without affecting the characteristics of the composition of the cheese.

The fat content in the cheeses analyzed directly after ripening ranged from $25.5 \%$ (for the cheese with dried carrots) to $29.7 \%$ (for the cheese with onion). While, after refrigerated storage, the fat content in the products was higher as a result of evaporation of part of the water in the product during this period. The highest fat content in the final product after the end of storage was determined in the cheese with the onion addition, while the lowest fat concentration was recorded for the carrot-supplemented cheese (Table 3). However, the differences between the products were not statistically significant $(\mathrm{P}>0.05)$.

The addition of the vegetables contributed to an increase in the $\mathrm{NaCl}$ content of the products (Table 3). The higher salt content recorded in the stored products was most probably related to biochemical conversions (including proteolysis) and intensified water loss (compared to the first analyzed stage of cheese production) contributing to a higher concentration and diffusion of $\mathrm{NaCl}$ in the cheese mass.

Determination of the antioxidant potential (Table 3) measured by FRAP indicated that the antioxidant activity of the tested products ranged from $1.48 \pm 0.11 \mu \mathrm{mol}$ of Trolox $/ \mathrm{g}$ (variant of the control ripened cheese) to $4.1 \pm 0.3 \mu \mathrm{mol}$ of Trolox/g (ripened cheese containing tomatoes).

The results of the analyses showed that each of the applied vegetable additives contributed to an increase in the antioxidant properties of the cheese products. Similar effects were demonstrated by Lee et al. [28], who reported higher antioxidant properties of Cheddartype cheese fortified with an Inula britannica flower extract. 
The antioxidant properties of the ripened cheeses were highly correlated with the content of total phenolic compounds $(\mathrm{R}=0.94 ; \mathrm{p}=0.05)$. This is in agreement with findings described by Lee et al. [28] suggesting that the scavenging activity of cheeses increased proportionally to the total phenolic content. While in case of the cool-stored cheeses, the correlation between total content of phenolic compounds and antioxidant activity was lower and it was not statistically significant (i.e. $R=0.6 ; \mathrm{p}=0.05$ ). A slight decrease in the antioxidant activity was observed in cheeses supplemented with tomatoes, onions, and carrots, whereas increased values of bioactivity was noted for cheeses with the broccoli addition (Table 3 ).

The results showed that the variants of organic cheeses exhibited antioxidant properties. This corresponds to the findings described by Han et al. [27] suggesting that supplementation of cheese curd with some plant additives e.g. whole grape extract, green tea extract, or dehydrated cranberry powder, which contain a wide range of bioactive compounds (including polyphenols), may significantly enhance the antioxidant properties of final cheese products.

\section{Texture profile analysis (TPA)}

The analysis of the TPA results showed differences among the tested cheeses in terms of textural parameters (Table 4). The highest hardness after ripening and refrigerating storage was observed for cheeses obtained with the addition of dried onion, whereas the lowest values of this texture parameter were recorded for the carrot-supplemented cheeses.

The refrigerated storage reduced the hardness and adhesion values only in the case of cheeses produced with the addition of onions, while the other variants showed an increase in this parameter after the end of the refrigerated storage.

The results of research performed by some authors indicate that hardness of cheeses increases together with the time of ripening [30], while others have observed an opposite tendency [31,32]. Whereas, Delgado et al. [33] indicated that hardness and adhesiveness significantly increased during ripening of raw goat milk cheeses (Ibores cheese), which may be explained by the progressive loss of moisture in the process of maturation. Similarly, Pinho et al. [34] indicated a decrease in hardness during ripening of Terrincho raw ewe milk cheese. The decrease in the hardness parameter in samples of cheeses supplemented with carrots or onions observed in our research corresponds to the results obtained by Van Hekken et al. [35], who analyzed Monterey Jack goat milk cheese and analyses of Torta del Casar raw ewe milk cheese described by Delgado et al. [36].

We observed that the refrigerated storage reduced the fracturability of the control cheeses as well as products with addition of onions or tomatoes (Table 4). The other variants of the final products analyzed after the refrigeration storage showed an increase in the value of this texture parameter. Moreover, the refrigeration storage reduced the values of springiness, cohesiveness, and chewiness of all the organic cheeses with the exception of products containing dried onions, which exhibited a higher cohesiveness value after the refrigerated storage. Similar findings have been described by Delgado et al. [33], who noted a significant decrease in the values of cohesiveness and springiness up to day 60 of Ibores cheese maturation. This is apparently connected with the fact that cohesiveness decreased through breakage of the casein network, while the lower values of springiness were a consequence of moisture loss and an increase in the fat concentration in the cheese matrix [37]. Moreover, a decrease in cohesiveness and springiness might also be a result of increased content of polypeptide nitrogen with simultaneous reduction of casein nitrogen occurring in the process of cheese maturation [33]. 
Table 4

Comparison of the texture parameters of cheese variants analyzed after the ripening process and in the final products.

\begin{tabular}{|c|c|c|c|c|c|c|c|c|}
\hline \multirow[b]{2}{*}{ 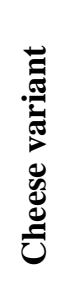 } & \multirow[b]{2}{*}{ 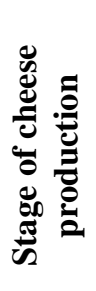 } & \multicolumn{7}{|c|}{ Texture parameter } \\
\hline & & 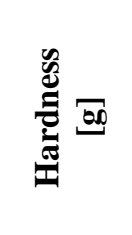 & 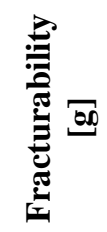 & 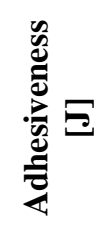 & 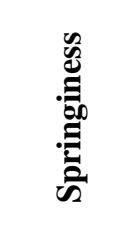 & 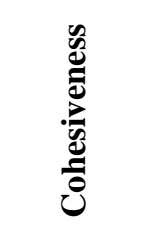 & 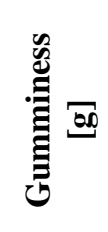 & $\underbrace{\infty}_{0}$ \\
\hline \multirow{2}{*}{$\begin{array}{l}\overline{0} \\
\stackrel{\Xi}{0} \\
ن\end{array}$} & $\mathrm{AR}$ & $\begin{array}{l}1061.5 \\
\pm 62.2^{\mathrm{c}}\end{array}$ & $\begin{array}{c}7.68 \\
\pm 0.20^{1} \\
\end{array}$ & $\begin{array}{r}17.9 \\
\pm 4.3^{\mathrm{a}} \\
\end{array}$ & $\begin{array}{c}0.454 \\
\pm 0.033^{\text {ef }} \\
\end{array}$ & $\begin{array}{c}0.244 \\
\pm 0.029^{\mathrm{f}} \\
\end{array}$ & $\begin{array}{l}254.8 \\
\pm 24.5^{\mathrm{f}}\end{array}$ & $\begin{array}{r}115.8 \\
\pm 15.1^{\mathrm{g}} \\
\end{array}$ \\
\hline & ARS & $\begin{array}{c}1158.7 \\
\pm 109.1^{\mathrm{d}} \\
\end{array}$ & $\begin{array}{c}6.30 \\
\pm 1.18^{\mathrm{j}} \\
\end{array}$ & $\begin{array}{r}22.8 \\
\pm 7.5^{\mathrm{c}} \\
\end{array}$ & $\begin{array}{c}0.327 \\
\pm 0.014^{\mathrm{bc}} \\
\end{array}$ & $\begin{array}{c}0.170 \\
\pm 0.014^{\mathrm{abc}} \\
\end{array}$ & $\begin{array}{l}192.5 \\
\pm 3.9^{c}\end{array}$ & $\begin{array}{c}61.7 \\
\pm 4.5^{\mathrm{c}} \\
\end{array}$ \\
\hline \multirow{2}{*}{$\stackrel{5}{\frac{5}{3}}$} & $\mathrm{AR}$ & $\begin{array}{c}1893.9 \\
\pm 138.5^{1}\end{array}$ & $\begin{array}{c}5.02 \\
\pm 0.67^{\mathrm{e}}\end{array}$ & $\begin{array}{c}59.7 \\
\pm 13.6^{\mathrm{h}}\end{array}$ & $\begin{array}{c}0.585 \\
\pm 0.052^{\mathrm{h}}\end{array}$ & $\begin{array}{c}0.179 \\
\pm 0.013^{\mathrm{bcd}}\end{array}$ & $\begin{array}{r}255.9 \\
\pm 25.2^{\mathrm{g}}\end{array}$ & $\begin{array}{r}149.7 \\
\pm 15.3^{\mathrm{k}}\end{array}$ \\
\hline & ARS & $\begin{array}{r}1768.6 \\
\pm 131.6^{\mathrm{k}} \\
\end{array}$ & $\begin{array}{c}4.51 \\
\pm 0.53^{\mathrm{d}} \\
\end{array}$ & $\begin{array}{c}38.7 \\
\pm 12.4^{\mathrm{f}} \\
\end{array}$ & $\begin{array}{c}0.435 \\
\pm 0.025^{\mathrm{de}} \\
\end{array}$ & $\begin{array}{c}0.192 \\
\pm 0.034^{\text {cde }} \\
\end{array}$ & $\begin{array}{r}331.5 \\
\pm 76.1^{\mathrm{k}} \\
\end{array}$ & $\begin{array}{r}128.6 \\
\pm 30.1^{\mathrm{h}} \\
\end{array}$ \\
\hline \multirow{2}{*}{ 焉 } & AR & $\begin{array}{r}1183.6 \\
\pm 136.2^{\mathrm{e}} \\
\end{array}$ & $\begin{array}{c}3.77 \\
\pm 0.61^{\mathrm{b}} \\
\end{array}$ & $\begin{array}{c}38.8 \\
\pm 7.6^{\mathrm{g}} \\
\end{array}$ & $\begin{array}{c}0.491 \\
\pm 0.061^{\mathrm{g}} \\
\end{array}$ & $\begin{array}{c}0.200 \\
\pm 0.019^{\text {de }} \\
\end{array}$ & $\begin{array}{r}225.1 \\
\pm 34.9^{\mathrm{e}} \\
\end{array}$ & $\begin{array}{r}109.4 \\
\pm 19.7^{\mathrm{f}} \\
\end{array}$ \\
\hline & ARS & $\begin{array}{r}1642.9 \\
\pm 174.5^{j} \\
\end{array}$ & $\begin{array}{c}6.22 \\
\pm 0.70^{\mathrm{i}} \\
\end{array}$ & $\begin{array}{r}110.7 \\
\pm 14.9^{j} \\
\end{array}$ & $\begin{array}{c}0.341 \\
\pm 0.039^{\mathrm{bc}}\end{array}$ & $\begin{array}{c}0.162 \\
\pm 0.019^{\mathrm{ab}} \\
\end{array}$ & $\begin{array}{c}224.1 \\
\pm 83.2^{\mathrm{d}} \\
\end{array}$ & $\begin{array}{c}99.4 \\
\pm 20.4^{\mathrm{d}} \\
\end{array}$ \\
\hline \multirow{2}{*}{$\stackrel{5}{0}$} & AR & $\begin{array}{l}1412.1 \\
\pm 49.1^{\mathrm{h}}\end{array}$ & $\begin{array}{c}4.04 \\
\pm 1.03^{\mathrm{c}}\end{array}$ & $\begin{array}{c}18.4 \\
\pm 6.6^{\mathrm{b}}\end{array}$ & $\begin{array}{c}0.409 \\
\pm 0.019^{\mathrm{d}}\end{array}$ & $\begin{array}{c}0.209 \\
\pm 0.031^{\mathrm{e}}\end{array}$ & $\begin{array}{r}255.9 \\
\pm 49.8^{\mathrm{g}}\end{array}$ & $\begin{array}{r}143.9 \\
\pm 28.4^{\mathrm{j}}\end{array}$ \\
\hline & ARS & $\begin{array}{c}1399.1 \\
\pm 142.7^{\mathrm{g}} \\
\end{array}$ & $\begin{array}{c}5.36 \\
\pm 0.72^{\mathrm{f}} \\
\end{array}$ & $\begin{array}{c}35.2 \\
\pm 6.3^{\mathrm{e}} \\
\end{array}$ & $\begin{array}{c}0.406 \\
\pm 0.064^{\mathrm{d}} \\
\end{array}$ & $\begin{array}{c}0.195 \\
\pm 0.019^{\text {cde }} \\
\end{array}$ & $\begin{array}{r}315.4 \\
\pm 83.2^{\mathrm{i}} \\
\end{array}$ & $\begin{array}{r}138.1 \\
\pm 31.8^{\mathrm{i}} \\
\end{array}$ \\
\hline \multirow{2}{*}{ 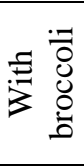 } & AR & $\begin{array}{l}1283.7 \\
\pm 60.5^{\mathrm{f}} \\
\end{array}$ & $\begin{array}{r}6.06 \\
\pm 0.95^{\mathrm{h}} \\
\end{array}$ & $\begin{array}{c}27.9 \\
\pm 2.0^{\mathrm{d}} \\
\end{array}$ & $\begin{array}{c}0.477 \\
\pm 0.011^{\mathrm{fg}} \\
\end{array}$ & $\begin{array}{c}0.253 \\
\pm 0.001^{\mathrm{f}} \\
\end{array}$ & $\begin{array}{l}318.4 \\
\pm 22.1^{\mathrm{j}} \\
\end{array}$ & $\begin{array}{l}152.1 \\
\pm 13.7^{1} \\
\end{array}$ \\
\hline & ARS & $\begin{array}{c}1416.3 \\
\pm 277.5^{\mathrm{i}}\end{array}$ & $\begin{array}{c}7.07 \\
\pm 0.87^{\mathrm{k}} \\
\end{array}$ & $\begin{array}{r}117.9 \\
\pm 24.4^{\mathrm{k}} \\
\end{array}$ & $\begin{array}{c}0.352 \\
\pm 0.069^{c}\end{array}$ & $\begin{array}{c}0.181 \\
\pm 0.011^{\text {bcde }} \\
\end{array}$ & $\begin{array}{r}274.9 \\
\pm 62.5^{\mathrm{h}} \\
\end{array}$ & $\begin{array}{l}105.5 \\
\pm 7.9^{\mathrm{e}} \\
\end{array}$ \\
\hline \multirow{2}{*}{ 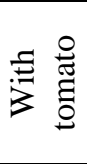 } & AR & $\begin{array}{c}882.3 \\
\pm 137.2^{\mathrm{b}} \\
\end{array}$ & $\begin{array}{c}5.79 \\
\pm 0.53^{\mathrm{g}} \\
\end{array}$ & $\begin{array}{l}106.8 \\
\pm 3.2^{\mathrm{i}}\end{array}$ & $\begin{array}{c}0.314 \\
\pm 0.036^{\mathrm{ab}} \\
\end{array}$ & $\begin{array}{c}0.166 \\
\pm 0.004^{\mathrm{abc}}\end{array}$ & $\begin{array}{r}134.6 \\
\pm 14.1^{\mathrm{a}} \\
\end{array}$ & $\begin{array}{c}44.3 \\
\pm 6.9^{\mathrm{a}} \\
\end{array}$ \\
\hline & ARS & $\begin{array}{c}983.3 \\
\pm 115.4^{\mathrm{a}} \\
\end{array}$ & $\begin{array}{c}2.82 \\
\pm 0.41^{\mathrm{a}} \\
\end{array}$ & $\begin{array}{l}142.1 \\
\pm 11.9^{1} \\
\end{array}$ & $\begin{array}{c}0.288 \\
\pm 0.059^{\mathrm{a}} \\
\end{array}$ & $\begin{array}{c}0.146 \\
\pm 0.007^{\mathrm{a}} \\
\end{array}$ & $\begin{array}{r}140.2 \\
\pm 22.8^{\mathrm{b}} \\
\end{array}$ & $\begin{array}{r}44.4 \\
\pm 9.4^{\mathrm{b}} \\
\end{array}$ \\
\hline
\end{tabular}

Explanation notes: AR- cheeses analyzed directly after finishing the ripening process; ARS- final products analyzed after refrigerated storage; The parameters were calculated from texture profile analysis (TPA). The results are given as mean values \pm standard deviation $(\overline{\mathrm{x}} \pm \mathrm{s} / \mathrm{SD} ; \mathrm{n}=6)$. Means followed by different lowercase letters (a-l) in the same column (texture parameter referring to all tested cheeses variants after ripening and after refrigerated storage) denote significant differences $(\mathrm{P}<0.05)$.

Changes in gumminess were noticed after the ripening and refrigerated storage period. The cold storage reduced the values of this texture parameter in the control cheeses and the broccoli-supplemented products, whereas an increase in the values of this parameter was noted in the other tested variants. 
The differences in the texture of the final products can be attributed to the different properties of the additives influencing the activity of the starter culture, which was reflected in further biochemical processes occurring during maturation and refrigerated storage.

\section{Analysis of color parameters}

The results of the instrumental analysis of the color of the cheeses are presented in the Table 5.

The L* parameter determines the brightness of the tested samples (the higher the value of this parameter, the lighter the color of the sample). In the analyzed cheeses, the $\mathrm{L}^{*}$ parameter ranged from 46.38 (cheese with beetroot) to 83.74 (cheese without additives control). After the period of cold storage, the value of this parameter decreased in all the samples except for the cheese with carrots, for which a slight increase in the value of $\mathrm{L}^{*}$ was observed. An opposite tendency was reported by Delgado et al. [33] in Ibores cheese during ripening (samples were analyzed on maturation days 1,30,60, and 90), in which the lightness parameter (CIE L*) significantly increased throughout the ripening process. However, these differences might be related to the differences in the specificity of goat`s and cow`s milk and the longer period of Ibores cheese ripening, where proteolysis was more intensive.

The present results showed that the use of the vegetable additives decreased the $\mathrm{L}^{*}$ parameter. A similar effect was observed in studies conducted by Golmakani et al. [38], who assessed the effects of Spirulina concentrations on the survival of $L$. casei strains in bacteriologically acidified feta-type (BAF) cheese. They indicated that the addition of Spirulina significantly reduced the brightness of the cheese; moreover, the $\mathrm{L}^{*}$ values decreased by increasing the Spirulina concentration.

The $\mathrm{a}^{*}$ parameter reflects color changes in the scale from green (negative values) to red. The highest red color value was noted for the control cheese samples (4.00) and the beetrootcontaining cheeses (21.96) after the process of maturation. All vegetable additives contributed to an increase in the red color in the cheeses. The process of refrigerated storage of the control cheeses contributed to a slight increase in the value of the $a^{*}$ parameter in these products. In addition, increased values of this parameter were also observed in samples of cheeses supplemented with red onion or tomato, while a decrease in the $\mathrm{a}^{*}$ parameter value was recorded in the other samples.

It has been reported that the $\beta$-carotene (belonging to carotenoids group) level in dairy products is correlated with the yellow color [24], which is in agreement with the present results, especially in the case of the tomato- or carrot-supplemented products (Table 3 and Table 5).

The $b^{*}$ parameter determines the color changes from blue (negative values) to yellow. In all cheeses with vegetable additives, except for the cheese with the beetroot addition, the values of the $b^{*}$ parameter were similar to the values noted for the control product and ranged from 29.02 (carrot-supplemented cheese) to 30.68 (broccoli-containing cheese). In turn, the beetroot-supplemented cheese was characterized by blue color $(-5.69)$.

These results indicate that the process of refrigerated storage induced a slight change in the value of the $b^{*}$ parameter in most of the analyzed samples. An increase in the proportion of yellow color was observed in the stored control samples and cheeses with the beetroot and tomato additives, whereas reduced values of this parameter were observed in cheeses containing onion, carrot, and broccoli. 
Table 5

Comparison of the color parameters in the variants of cheeses analyzed after the ripening process and refrigerated storage

\begin{tabular}{|c|c|c|c|c|}
\hline \multirow{2}{*}{$\begin{array}{c}\text { Cheese } \\
\text { variant }\end{array}$} & \multirow[b]{2}{*}{$\begin{array}{c}\text { Stage of cheese } \\
\text { production }\end{array}$} & \multicolumn{3}{|c|}{ Color parameter } \\
\hline & & $\mathbf{L}^{*}$ & $\mathbf{a}^{*}$ & $\mathbf{b}^{*}$ \\
\hline \multirow{2}{*}{ Control } & After ripening & $83.74 \pm 1.27^{\mathrm{k}}$ & $4.00 \pm 0.39^{\mathrm{b}}$ & $29.39 \pm 2.19^{\mathrm{g}}$ \\
\hline & After refrigerated storage & $79.5 \pm 0.21^{\mathrm{i}}$ & $4.89 \pm 0.08^{\mathrm{d}}$ & $31.35 \pm 0.36^{j}$ \\
\hline \multirow{2}{*}{ With onion } & After ripening & $78.17 \pm 3.77^{\mathrm{h}}$ & $5.11 \pm 0.39^{\mathrm{e}}$ & $29.95 \pm 5.59^{\mathrm{h}}$ \\
\hline & After refrigerated storage & $77.63 \pm 0.5^{\mathrm{g}}$ & $6.61 \pm 0.69^{f}$ & $27.03 \pm 0.8^{\mathrm{d}}$ \\
\hline \multirow{2}{*}{ With beetroot } & After ripening & $46.38 \pm 2.96^{\mathrm{b}}$ & $21.96 \pm 2.28^{\mathrm{k}}$ & $-5.69 \pm 1.52^{\mathrm{a}}$ \\
\hline & After refrigerated storage & $41.92 \pm 0.71^{\mathrm{a}}$ & $19.07 \pm 2.96^{j}$ & $2.04 \pm 4.19^{\mathrm{b}}$ \\
\hline \multirow{2}{*}{ With carrot } & After ripening & $75.9 \pm 1.86^{\mathrm{f}}$ & $11.97 \pm 3.39^{\mathrm{i}}$ & $29.02 \pm 2.36^{\mathrm{e}}$ \\
\hline & After refrigerated storage & $77.63 \pm 0.5^{\mathrm{g}}$ & $6.61 \pm 0.69^{f}$ & $27.03 \pm 0.8^{\mathrm{d}}$ \\
\hline \multirow{2}{*}{ With broccoli } & After ripening & $73.07 \pm 2.5^{\mathrm{e}}$ & $4.63 \pm 1.46^{\mathrm{c}}$ & $30.68 \pm 3.61^{\mathrm{i}}$ \\
\hline & After refrigerated storage & $69.1 \pm 2.58^{\mathrm{d}}$ & $2.62 \pm 0.55^{\mathrm{a}}$ & $25.66 \pm 1.64^{\mathrm{c}}$ \\
\hline \multirow{2}{*}{ With tomato } & After ripening & $81.48 \pm 4.47^{\mathrm{j}}$ & $7.1 \pm 2.54^{\mathrm{g}}$ & $29.23 \pm 2.44^{\mathrm{f}}$ \\
\hline & After refrigerated storage & $68.8 \pm 1.45^{\mathrm{c}}$ & $11.38 \pm 0.9^{\mathrm{h}}$ & $32.19 \pm 0.8^{\mathrm{k}}$ \\
\hline
\end{tabular}

Explanation notes: The results are given as mean values \pm standard deviation $(\overline{\mathrm{x}} \pm \mathrm{s} / \mathrm{SD} ; \mathrm{n}=10)$. Means followed by different lowercase letters (a-k) in the same column (color parameter) denote significant differences $(\mathrm{p}<0.05)$.

\section{Conclusion}

1. The applied vegetable additives had a varied effect on cheese texture parameters. The highest hardness after ripening and refrigerating storage was observed for cheeses obtained with the addition of dried onion, whereas the lowest values of this texture parameter were recorded for the carrot-supplemented cheeses.

2. The used plant-derived additives significantly increased the level of bioactive components and enhanced the antioxidant properties of cheeses after process of ripening.

3. After refrigerated storage the highest antioxidant properties exhibited the cheeses produced with the addition of broccoli and tomato.

4. The tested vegetable-derived additives contributed to increase in the red color of cheeses mass, all vegetable additives (especially carrot, tomato and beetroot) had a positive effect on the colouring of the cheese mass exhibiting a potential as an alternative to conventional cheese dyes.

\section{References}

1. Dalsgaard T.K., Sørensen J., Bakman M., Vognsen L., Nebel C., Albrechtsen R., Nielsen J.H. (2010) Light-induced protein and lipid oxidation in cheese: Dependence on fat content and packaging conditions, Dairy Sci. Technol., 90, pp. 565 - 577.

2. Bergamo P., Fedele E., Iannibelli L., Marzillo G. (2003), Fat-soluble vitamin contents and fatty acid composition in organic and conventional Italian dairy products, Food Chem., 82, pp. 625631. 
3. Bisig W., Eberhard P., Collomb M., Rehberger B. (2007), Influence of processing on the fatty acid composition and the content of conjugated linoleic acid in organic and conventional dairy products - a review, Lait, 87, pp. 1-19.

4. Dos Reis L.C.R., de Oliveira V.R., Hagen M.E.K. Jablonski A., Flôres S.H., de Oliveira Rio A. (2015), Effect of cooking on the concentration of bioactive compounds in broccoli (Brassica oleracea var. avenger) and cauliflower (Brassica oleracea var. Alphina F1) grown in an organic system, Food Chem., 172, pp. 770-777.

5. Kahl J., Baars T., Bügel S., Busscher N., Huber M., Kusche D., Rembiałkowska E., Schmid O., Seidel K., Taupier-Letage B., Velimirov A., Załecka A. (2012), Organic food quality: a framework for concept, definition and evaluation from the European Perspective, J. Sci. Food Agric., 92(14), pp. 2760-2765.

6. Michaelsen K.F., Pedersen S. B., Skafte L., Jaeger P., Peitersen B. (1988), Infrared analysis for determining macronutrients in human milk, J. Pediatr. Gastroenterol. Nutr., 7(2), pp. 229-235.

7. Lucera A., Costa C., Marinelli V., Saccotelli M.A., Del Nobile, M.A., Conte A. (2018), Fruit and Vegetable By-Products to Fortify Spreadable Cheese, Antioxidants (Basel), 7(5), pii: E61.

8. Fish W.W., Perkins-Veazie P., Collin J.K. (2002), A Quantitative Assay for Lycopene That Utilizes Reduced Volumes of Organic Solvents, J. Food Compos. Anal., 15(3), pp. 309-317.

9. Lichtenthaler H.K, Buschmann C. (2001), Chlorophylls and Carotenoids: Measurement and Characterization by UV-VIS Spectroscopy. In: Wrolstad, R.E., Acree T.E., An H., Decker E.A., Penner M.H., Reid D.S., Schwartz S.J., Shoemaker C.F. and Sporns, P., Eds., Current Protocols in Food Analytical Chemistry (CPFA), John Wiley and Sons, New York, pp. F4.3.1-F4.3.8.

10. Gościnna K., Walkowiak-Tomczak D., Czapski J. (2014), Effect of heating conditions of solutions of red beet juice concentrate on colour parameters and betalain contents, Aparatura Badawcza i Dydaktyczna, 19(12), 183-189.

11. Fuleki T., Francis F.J. (1968), Quantitative methods for anthocyanins, J. Food Sci., 33, pp. 7277.

12. Jia Z., Tang M., Wu J. (1998), The determination of flavonoid contents in mulberry and their scavenging effects on superoxides radicals, Food Chem., 64(4), pp. 555-559.

13. Jabłońska-Ryś E., Sławińska A., Szwajgier D. (2016), Effect of lactic acid fermentation on antioxidant properties and phenolic acid contents of oyster (Pleurotus ostreatus) and chanterelle (Cantharellus cibarius) Mushrooms, Food Sci. Biotechnol., 25(2), pp. 439-444.

14. PN-A-75101-12:1990. Przetwory owocowe i warzywne -- Przygotowanie próbek i metody badań fizykochemicznych - Oznaczanie zawartości sumy karotenoidów i beta-karotenu.

15. AOAC (2007) (Method 920.124) Official Methods of Analysis Ch. 33, Association of Official Analytical Chemists, Arlington, 84.

16. Radzki W., Ziaja-Sołtys, M., Nowak J., Dominik J., Bogucka-Kocka A., Sławińska A., MichalakMajewska M., Jabłońska-Rys E., Kuczumow A. (2019), Impact of processing on polysaccharides obtained from button mushroom (Agaricus bisporus), Int. J. Food Sci. Technol., 54(4), pp. $1405-$ 1412.

17. Sołowiej B. (2012), Evaluation of rheological properties of reduced-fat processed cheese analogues, Żywność. Nauka. Technologia. Jakość, 80, pp. 60-71.

18. Nielsen S.S. (2010), Sodium determination using ion selective electrodes. Mohr titration and test strips. In Food Analysis Laboratory Manual. S. S. Nielsen. Ed. Springer. New York. NY. USA., pp. $75-85$.

19. ISO 1735:2004 [IDF 5:2004] Cheese and Processed Cheese Products. Determination of Fat Content. Gravimetric Method, International Organization for Standardization: Geneva. Switzerland. 2004.

20. Carini E., Vittadini E., Curti E., Antoniazzi F., Viazzani P. (2010), Effect of different mixers on physicochemical properties and water status of extruded and laminated fresh pasta, Food Chem., 122(2), pp. 462-469.

21. Kulczyński B., Gramza-Michałowska A., Kobus-Cisowska J., Kmiecik D. (2017), The role of carotenoids in the prevention and treatment of cardiovascular disease - current state of knowledge, J. Funct. Foods, 38, pp. 45-65. 
22. Alda L.M., Gogoaşă I, Bordean D.M., Gergen I., Alda S., Moldovan C., Niţă L. (2009), Lycopene content of tomatoes and tomato products, J. Agroaliment. Proc. Technol., 15(4), pp. 540-542.

23. Rizk E.M., El-Kady A.T., El-Bialy A.R. (2014), Charactrization of carotenoids (lyco-red) extracted from tomato peels and its uses as natural colorants and antioxidants of ice cream. Ann. Agric. Sci., 59, pp. 53-61.

24. Kilcawley K.N., Faulkner H., Clarke H.J., O'Sullivan M.G., Kerry J.P. (2018), Factors Influencing the Flavour of Bovine Milk and Cheese from Grass Based versus Non-Grass Based Milk Production Systems, Foods,7(3), pii: E37.

25. Faulkner H., O'Callaghan T.F., McAuliffe S., Hennessy D., Stanton C., O'Sullivan M.G., Kerry J.P., Kilcawley K.N. (2018), Effect of different forage types on the volatile and sensory properties of bovine milk, J. Dairy Sci., 101(2), pp. 1034-1047.

26. Kasangi D. M., Shitandi A.A., Shalo P.L., Mbugua S. K. (2010), Effect of spontaneous fermentation of cowpea leaves (Vigna unguiculata) on proximate composition, mineral content, chlorophyll content and beta-carotene content, Int. Food Res. J., 17(3), pp. 721-732.

27. Han J., Britten M., St-Gelais D., Champagne C.P., Fustier P., Salmieri S., Lacroix M. (2011), Polyphenolic compounds as functional ingredients in cheese, Food Chem., 124(4), pp. 15891594.

28. Lee N.K., Jeewanthi R.K., Park E.H., Paik H.D. (2016), Short communication: Physicochemical and antioxidant properties of Cheddar-type cheese fortified with Inula britannica extract, J. Dairy Sci., 99, pp. 83-88.

29. Rashidinejad A., Birch E. J., Everett D.W. (2016), Antioxidant activity and recovery of green tea catechins in full-fat cheese following gastrointestinal simulated design, J. Food Compos. Anal., 48, pp. 13-24.

30. Młynek K., Oler A., Zielińska K, Tkaczuk J., Zawadzka W. (2018), The effect of selected components of milk and ripening time on the development of the hardness and melting properties of cheese, Acta Sci Pol Technol Aliment., 17(2), pp. 133-140.

31. Halkman K., Yetişmeyen A., Yildirim M., Yildirim Z. (1994), Research on the use of starter cultures in Kaşar cheese production, Turk. J. Agric. For. 18, pp. 365-377.

32. Güven M., Karaca V., Kaçar A., Hayaloğlu A. (2002), Antimikrobiyal madde kullanımı ve ambalaj metaryelinin olgunlaşma süresince kaşar peynirinin özellikleri üzerine etkileri. Harran Üniversitesi Ziraat Fakültesi Dergisi, 6, pp. 13-23.

33. Delgado F. J., González-Crespo J., Cava R., Ramírez R. (2011), Proteolysis, texture and colour of a raw goat milk cheese throughout the maturation, Eur. Food Res. Technol., 233(3), pp. $483-$ 488.

34. Pinho E.M., Alves M.M., Ferreira I.M. (2004), Chemical, physical, and sensorial characteristics of "Terrincho" ewe cheese: changes during ripening and intravarietal comparison, J. Dairy Sci., 87(2), pp. 249-257.

35. Van Hekken D.L., Tunick M.H., Park Y.W. (2004), Rheological and proteolytic properties of Monterey Jack goat milk cheese during months aging, J. Agric. Food Chem., 52(17), pp. 5372 5377.

36. Delgado F.J., Rodríguez-Pinilla J., Gonzá Lez-Crespo J., Ramírez R., Roa I. (2010), Proteolysis and texture changes of a Spanish soft cheese ("Torta del Casar") manufactured with raw ewe milk and vegetable rennet during ripening, Int. J. Food Sci. Technol., 45(3), pp. 512-519.

37. Bryant A., Ustunol Z., Steffe J. (1995), Texture of Cheddar cheese as influenced by fat reduction, J. Food Sci., 60(6), pp. 1216-1219.

38. Golmakani M.T., Soleimanian-Zad S., Alavi N., Nazari E., Eskandari M.H. (2018), Effect of Spirulina (Arthrospira platensis) powder on probiotic bacteriologically acidified feta-type cheese, J. Appl. Phycol., 31, pp. 1085-1094. 